\title{
The impact of irrigation farming on livelihood strategies among smallholder farmers in the North West Province, South Africa
}

\author{
A. Balarane \& O. I. Oladele \\ Department of Agricultural Economics and Extension, \\ North-West University, South Africa
}

\begin{abstract}
This study aimed to determine the impact of irrigation farming on livelihood strategies among smallholder farmers in the North West Province, South Africa. Simple random sampling techniques were used to select 66 male farmers from the population of the study and data was collected through the use of a structured questionnaire and subjected to analysis using frequencies, percentage and multiple regression analysis. The results showed that about $9 \%$ of the respondents were below the age of 40 years. While $65 \%$ of the respondents were above the age of 50 years. The result also showed that $3 \%$ of the respondents are divorced while $71.2 \%$ were still married. The results showed that only $7.6 \%$ of the irrigation land is privately owned and $92.4 \%$ belongs to the chief. About $54.5 \%$ of respondents survive from government grants and $22.7 \%$ survive from seasonal jobs. About $53 \%$ of the farmers indicated that they are involved in irrigation farming, only because the existing irrigation schemes is their only source of income. While about $47 \%$ of the farmers are in the irrigation farming for personal interest. Farmers showed that they have adequate access to livelihood aspiration such as physical capital, human capital, natural capital and skill training but access to financial capital, which includes credit from the banks, cooperative and government subsidies is not adequate. Significant determinants of livelihood strategies of farmers were marital status (2.43), size of household $(t=5.41)$, nonfarm activity $(\mathrm{t}=1.73)$ and income $(\mathrm{t}=6.59)$.

Keywords: irrigation farming, livelihood strategies, smallholder farmers, South Africa.
\end{abstract}




\section{Introduction}

Agriculture is multi-disciplinary and over time, agricultural science has grown as a means of addressing real life's multi-faceted problems. Agricultural science includes environment and natural resources management, among other disciplines. Agriculture is defined as the production, processing and distribution of food, fish, forest products and fiber. South Africa has an estimated 1.3 million ha of irrigated land for both commercial and subsistence agriculture. Irrigated agriculture consumes more than $60 \%$ of the groundwater. About two thirds of South African small holder irrigates schemes are dedicated to food plots of 300, 000 black people (Perret [1]). Demand for water is increasing worldwide, especially in developing countries. Increasing water scarcity implies that options for water resource development are becoming limited. This increased demand on water is due to population and economic growth, industrialization, urbanization, provision of water and sanitation services to previously disadvantaged people and environmental requirements.

Irrigation has long played a key role in feeding expanding populations and is undoubtedly destined to play a still greater role in the future (FAO [2]). It not only raises the yields of specific crops, but also prolongs the effective crop-growing period in areas with dry seasons, thus permitting multiple cropping (two or three, and sometimes four crops per year) where only a single crop could be grown otherwise. With the security provided by irrigation, additional inputs needed to intensify production further (pest control, fertilizers, improved varieties and better tillage) to become economically feasible. Irrigation reduces the risk of these expensive inputs being wasted by crop failure resulting from lack of water. The practice of irrigation consists of applying water to the part of the soil profile that serves as the root zone, for the immediate and subsequent use of the crop (FAO [3]). Well-managed irrigation systems are those that control the spatial and temporal supply of water so as to promote growth and yield, and to enhance the economic efficiency of crop production. Irrigation growth offers possibilities for reducing risks of food shortages at all levels, increasing the overall supply of food, creating economic opportunities for vulnerable people and improving dietary diversity and the quality of food consumed by farm households (Lyne et al. [4]).

Small-scale irrigation in South Africa originated mostly from a food security perspective and two types of schemes can historically be distinguished: 1) former Bantustan schemes, currently accounting for 46,000 to 47,500 ha and 2) community schemes or garden schemes representing about 50,000 ha (Backeberg [5]). The first type of scheme dates from the 1950s and 1960s. Their objective was to provide farmers in the homelands with opportunities to produce their own food and possibly a surplus for sale. The size of these schemes varied significantly, ranging from 30 to 2000 ha, with an average size of about 200 ha, and a fixed farm size per beneficiary of about $1.5 \mathrm{ha}$. These schemes however were neither financially viable nor self-sustaining since capital or operation costs were never covered by operation outputs and profit. Instead, under-pricing and government subsidisation of water infrastructure and services, and management by parastatal agencies generated dependency and ignorance on the farmers' side. 
After the reinstallation of democracy in South Africa, policies, including those for agriculture, were reformed and the homelands were reincorporated in the State. This study was designed to investigate the extent to which irrigation farming has impacted the livelihood strategies of smallholder farmers in irrigation farming and those who farm within the radius of the irrigation schemes. A livelihood comprises of the capabilities, assets (stores, resources, claims and access) and activities required for a means of living; a livelihood is sustainable if it can cope with and recover from stress and shocks, maintain or enhance its capabilities and assets, provide sustainable livelihood opportunities for the next generation and that which contributes net benefits to other livelihoods at local and global levels in the short and medium term. Ellis [6] postulates that livelihoods comprise of assets and activities and access to both of these factors determines the living gained by households or individuals. Households attempt to diversify their livelihood strategies by optimising the use of their capabilities and assets. Households with well-diversified assets and livelihood strategies can cope better than those with a more limited asset base and few livelihood resources (De Satgé [7]) thus creating a veritable safety net for these households. Diversified sources could include a combination of salaries or wages obtained through employment, remittances, social grants, and even income or perhaps food generated through agricultural activity.

Human capital includes the education and health status of household members and the ability of households to leverage income through employment. Social capital includes all social resources such as social networks, which households can draw upon to attain their goals. Natural capital refers to the land and natural resources to which households have access. Physical capital is essential to achieve livelihood goals and includes access to basic services such as water, sanitation and electricity, as well as equipment and mediums of communication. The main objective of the study was to assess the impact of irrigation farming on livelihood strategies among smallholder farmers in the North West Province, South Africa. The specific objectives of the study were to describe the socio-economic profile of farmers in irrigation farming and to analyse the impact of irrigation farming on the livelihood strategies of farmers.

\section{Materials and methods}

The study was conducted in three districts of the North West Province namely: Dr Ngaka Modiri Molema district, Bojanala district and Dr Ruth Segomotsi Mompati district. The rainfall pattern of the province occupies approximately $11 \%$ or $129,821 \mathrm{~km}^{2}$ of South Africa. The North West Province is mostly rural in nature with much of the area consisting of flat areas of scattered trees and grasslands. Thirty five percent of the population are in urban areas while sixty five percent in rural areas. North West Province produces a third of the country's maize and makes a contribution to the supply of other agricultural products such as tobacco, sunflower oil, cotton and wheat. Agriculture in the eastern parts mainly focuses on horticulture and livestock. The semi-arid central and western parts are more focused on livestock and game farming. The province has a well-developed 
commercial agricultural sector, while subsistence farming is a very prominent activity in the communal areas. The main economic sectors are agricultural, mining and tourism. From the list of irrigation farmers obtained from the North-West Department of Agriculture and Rural Development, simple random sampling technique was used to select 66 farmers who represented twenty three percent of the population. The targeted group were male farmers in the irrigation schemes and those who farm adjacent to the irrigation scheme. Data was collected through a structured questionnaire which was designed based on the objectives of the study. The questionnaire elicited household characteristics such as demographic information (gender, age, level of education), farm specific characteristics (number and class of livestock, crops grown, hectares and output), food and non-food expenditures, remittances, employment and income, and agricultural activities. Other sections focused on the contributions of irrigation on livelihoods. The data that was collected was then analysed with the Statistical Package for Social Science using frequencies, percentage and multiple regression. The linear regression model was used to isolate factors influencing the impact of irrigation farming on livelihood.

\section{Results and discussion}

The results in Table 1 indicate that 66 of the respondents were male farmers only. This is because the focus of the study was on only one gender. The demographic results also showed that $9 \%$ of the respondents are less than 40 years old. The majority of the farmers $(65 \%)$ were above the age of 50 years. The results revealed that $3 \%$ of respondents are divorced while $71.2 \%$ are still married, and $42.8 \%$ have only primary school educational level. Farmers indicated that low literacy level amongst them could be a result of the apartheid era that forced many South Africans to leave schools at an early age. According to Mutsvangwa [8], irrigation also empowers and emancipate socially. Punnet [9] gave an example of the Martha Fenai Pradesh scheme in India which has been successful.

\subsection{Types of farming enterprises practiced by farmers on irrigation farming}

The result in Figure 1 indicates that about $56 \%$ of the respondents produce maize. Maize is the most important source of food in South Africa and is only planted at less than one hectare by an average South African small-scale farmer. According to Dalelo [12] a diversity of crops is grown by small-scale farmers of South Africa and out of the diverse crops grown by rural households, maize is the major crop produced. The crop is favourable to the climatic conditions of the area as it is grown both on irrigated land and dry land. The majority of the smallholder farmers that produce maize in the study area have indicated that they use dry land and they depend on the amount of rainfall per season for better yields. The North West Province is ranked as the third main producer of the country's maize production and makes a contribution to the supply of other agricultural products such as tobacco, sunflower oil, cotton and wheat (DAFF [11]). 
Table 1: Demographics of farmers in the study area.

\begin{tabular}{|l|l|l|}
\hline Variable & Frequency & Percentage \\
\hline Age & & \\
\hline$<40$ & 6 & 9 \\
\hline $40-50$ & 18 & 26 \\
\hline Above 50 & 42 & 65 \\
\hline Marital status & & \\
\hline Single & 15 & 22.7 \\
\hline Married & 47 & 71.2 \\
\hline Widower & 2 & 3 \\
\hline Divorce & 2 & 3 \\
\hline Race & & \\
\hline African & 66 & 100 \\
\hline Religion & & \\
\hline Christianity & 55 & 83 \\
\hline Other & 11 & 17 \\
\hline Number of dependants & & \\
\hline$<5$ & 46 & 70 \\
\hline Above 5 & 20 & 30 \\
\hline Household size & & \\
\hline$<6$ & 42 & 64 \\
\hline Above 4 & 9 & 14 \\
\hline Educational level & & \\
\hline Primary school & 28 & 42.4 \\
\hline Secondary school & 13 & 19.7 \\
\hline High school & 13 & 19.7 \\
\hline College & 1 & 7.6 \\
\hline University & 5 & 27 \\
\hline No education & 6 & 4.5 \\
\hline Farming experience & 32 & \\
\hline$<5$ & 32 & \\
\hline $6-20$ & 16 & \\
\hline Above 20 & & \\
\hline $11-20$ & & \\
\hline Contact with extension workers & & \\
\hline No & & \\
\hline Yes & & \\
\hline & & \\
\hline
\end{tabular}


Table 1: Continued.

\begin{tabular}{|l|l|l|}
\hline Variable & Frequency & Percentage \\
\hline Frequency of contact & & \\
\hline Rarely & 39 & 59 \\
\hline Occasional & 23 & 35 \\
\hline Regularly & 4 & 6 \\
\hline Organization of the extension & & \\
\hline Government & 63 & 95.5 \\
\hline NGO & 2 & 3 \\
\hline Parastatal & 1 & 1.5 \\
\hline Number of workers & & \\
\hline$<5$ & 52 & 78.8 \\
\hline Above 5 & 14 & 21.2 \\
\hline Labour sources & & \\
\hline Self & 51 & 77 \\
\hline Family & 4 & 6 \\
\hline Hired & 11 & 17 \\
\hline Number of years in the irrigation & & \\
\hline$<10$ & 30 & 46 \\
\hline $12-20$ & 20 & 31 \\
\hline Above 20 & 16 & 23 \\
\hline Non farming activities & & \\
\hline No & 52 & 78.8 \\
\hline Yes & 14 & 21.2 \\
\hline Name them & & \\
\hline & & \\
\hline
\end{tabular}

About $25.5 \%$ of the respondents grow beetroot and $21.2 \%$ grow cabbage. According to Jackson and Steenhuis [10], a survey of horticultural production in Zimbabwe showed that irrigation farming enables the growing of green vegetables, wheat, tomatoes, cotton, maize and even sugar-cane among others. About $1.5 \%$ of the respondents grow tomatoes in the study area. This crop has the lowest average yields and this is attributed to difficulties of weather conditions and expenses attached to storage since there is no ready or nearby market for the perishables in the area. According to DAFF [13] tomatoes are produced in all of South Africa's Provinces, with Limpopo province being the dominant producer. The province accounts for more than seventy five percent of the total area planted to tomatoes. The other main producing areas for the crop are Mpumalanga and Eastern Cape provinces. Maize, which is the most important source of food in South Africa, is only planted at less than one hectare by an average South African small-scale farmer. 


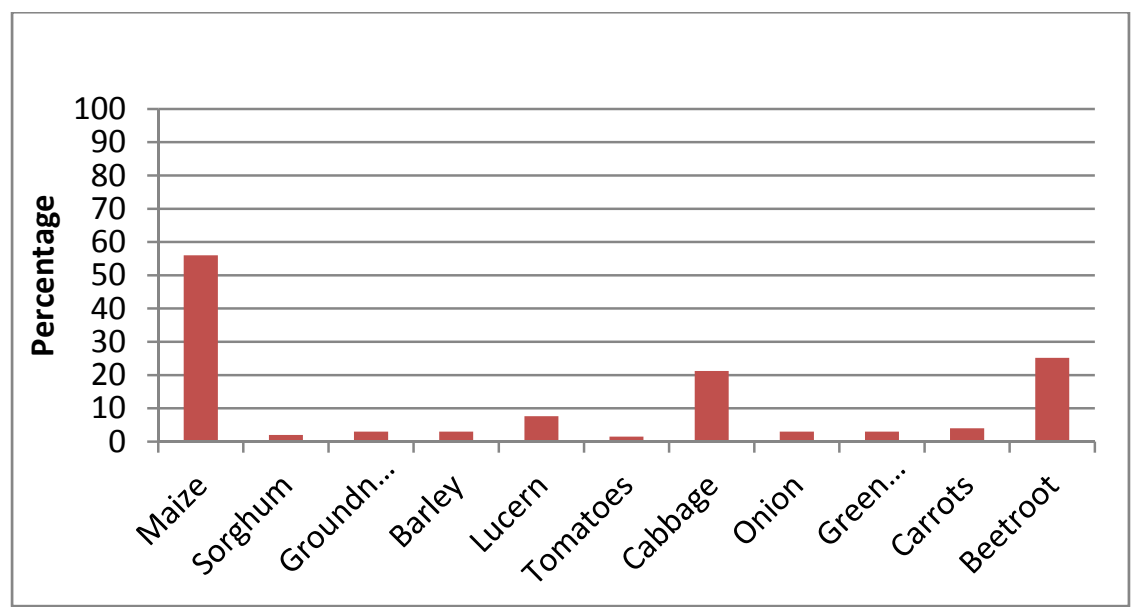

Figure 1: Farming enterprises practiced by farmers.

\subsection{Access to livelihood assets by irrigation farmers}

Access to financial capital - Table 2 shows access to livelihood assets by the farmers. From the list of 7 listed financial capital institutions about $74.9 \%$ of the farmers were not accessing credit from government subsidies. DAFF [14] reported that in South Africa the government have introduced developmental programmes such as CASP and LRAD; these are the government initiatives aimed at supporting famers in the form of grants for their farming development.

Access to banks $(66.36 \%)$ is not adequate to farmers. This could be attributed by the fact that farmers do not have title deeds for the land that they use and therefore it is very difficult for them to use this land as collateral to credit, while farmers indicated that informal borrowing from relatives is more available to them. Oladeebo and Oladeeboo [15] also found that smallholder farmers have relatively more access to informal and semiformal credit institutions than to formal credit institutions, in spite of the higher volume of credit at the disposal of formal institutions. In addition, the high repayment rate of loans recorded by informal and semiformal institutions could indicate that the loans are granted at affordable rates to the small-scale farmers and that subsidization may not be necessary. Oruonye and Musa [16] supported that access to agricultural credit constitutes a major challenge to small-scale farmers in Nigeria. This led the people in the area to evolve a local system of micro finance (bada kaka) to enable them to overcome the challenges in accessing production loans from banks. However, the evolution of the local micro finance (bada kaka) as indicated by most farmers in Nigeria has failed to achieve the desired result due to the harsh and exploitative conditions associated with it. Consequently, most farmers have continued to operate at the small scale due to a lack of access to micro credit. The inability of the farmers to access alternative sources of farm credit has compelled them to endure the 
exploitative tendencies of the middlemen (traders) through the bada kaka micro credit scheme over the years, and farmers do not even possess ownership deeds as a collateral to access financing from financial institutions.

\subsection{Access to physical capital by smallholder farmers}

From the 6 listed physical capital assets farmers were asked to indicate which of the assets are easily accessible to them. Farmers indicated that they have more adequate access to storage (89.4\%), market (81.8\%) and electricity (50\%). According to IFAD [17] market access plays a remarkable role in ensuring better income and welfare for smallholder farmers through diverse channels. By raising income, markets increase purchasing power, which in turn creates a demand for consumer goods and enhances farmer welfare. Market access can be improved with an increase in the flow of market information to the farmer, to broaden the information base of the farmer and reduce dependence on traders for price information. Without an institutional framework that facilitates information flow, access to information is dependent on social capital - neighbours, friends and relations.

Oduro et al. [18] argued that age and gender have negative and positive effects on market participation respectively. Older people tend to have more dependents and more subsistence activities hence low market participation.

Matriarchal households and households with more female members, especially with respect to dairy products, tend to be primarily involved in these production activities and therefore they positively affect market participation. Infrastructure and services are important defining parameters of market proximity and therefore effective market participation (Holloway et al. [19]). Farmers further indicated that access to transport $(51.5 \%)$ is available to them. According to Goletti and Wolff [20], transport generally marks the passage from one stage of the postharvest system to the next. Therefore, if the roads are poorly developed, it becomes difficult to move products from one stage to another. From the results farmers also indicated that access to roads $(39.4 \%)$ is inadequate. Physical capital is essential to achieve livelihood goals and include access to basic services such as water, transport and electricity, as well as markets. The majority of villages in rural areas are served by an inadequate and poorly maintained road network. These roads are mainly gravel and are severely eroded. The poor conditions of roads, which are often impassable during the rainy season, have an adverse effect on the transportation of produce (Montshwe [21]).

\subsection{Access to natural capital by smallholder farmers in the irrigation scheme}

Natural capital refers to the land and natural resources to which households have access. The result showed that $98.5 \%$ of the farmers have permission to occupy land from the chief while only $1.5 \%$ of the land is privately leased, because of the adaptation of the customary system of land allocation in rural areas of South Africa. 
There is no household that can claim formal ownership of the allocated piece of land. The land allocation and responsibility over it lie with the tribal authority, the Kgosi (chief).

Table 2: Access to livelihood assets by farmers.

\begin{tabular}{|c|c|c|c|c|}
\hline Financial capital & \multicolumn{2}{|c|}{ Availability } & Very adequate & $\begin{array}{l}\text { Not } \\
\text { adequate }\end{array}$ \\
\hline \multicolumn{5}{|l|}{ Access to credit } \\
\hline Banks & \multicolumn{2}{|l|}{$22(33.3)$} & $4(6.1)$ & $40(66.6)$ \\
\hline Cooperatives & \multicolumn{2}{|l|}{$26(39.4)$} & & $40(60.6)$ \\
\hline Money lenders & \multicolumn{2}{|l|}{$29(43.9)$} & $2(3.0)$ & $35(53)$ \\
\hline Relatives & \multicolumn{2}{|l|}{$41(62.1)$} & $2(3.0)$ & $23(34.9)$ \\
\hline Personal savings & \multicolumn{2}{|l|}{$43(65.2)$} & $6(9.0)$ & $17(25.8)$ \\
\hline Contractors & \multicolumn{2}{|l|}{$25(37.9)$} & $2(3.0)$ & $39(59.1)$ \\
\hline Government subsidies & \multicolumn{2}{|l|}{$5(7.6)$} & $12(18.2)$ & $49(74.3)$ \\
\hline \multicolumn{5}{|l|}{ Human capital } \\
\hline Training & & $44(66.6)$ & $22(33.4)$ \\
\hline Vocational training & \multicolumn{2}{|l|}{+2} & $32(48.5)$ & $34(51.5)$ \\
\hline Extension service & \multicolumn{2}{|l|}{$29(43.9)$} & $18(27.3)$ & $19(28.8)$ \\
\hline \multicolumn{5}{|l|}{ Skills training } \\
\hline Record keeping & \multicolumn{2}{|l|}{$34(51.5)$} & $7(10.6)$ & $25(37.9)$ \\
\hline Water management & \multicolumn{2}{|l|}{$32(48.5)$} & $13(19.7)$ & $19(31.8)$ \\
\hline Equipment handling & \multicolumn{2}{|l|}{$35(53.0)$} & $14(21.2)$ & $17(25.8)$ \\
\hline Financial management & \multicolumn{2}{|l|}{$25(37.9)$} & $12(18.2)$ & $29(43.9)$ \\
\hline Soil management & \multicolumn{2}{|l|}{$38(57.6)$} & $8(12.1)$ & $20(30.3)$ \\
\hline Crop protection & \multicolumn{2}{|l|}{$43(65.2)$} & $9(13.6)$ & $14(21.2)$ \\
\hline \multicolumn{5}{|l|}{ Physical capital } \\
\hline Transport & \multicolumn{2}{|l|}{$34(51.5)$} & $23(34.8)$ & $9(13.6)$ \\
\hline Water supply & \multicolumn{2}{|l|}{$20(30.2)$} & $24(36.4)$ & $21(33.4)$ \\
\hline Markets & \multicolumn{2}{|l|}{$12(18.2)$} & $54(81.8)$ & \\
\hline Road accessibility & \multicolumn{2}{|l|}{$22(33.3)$} & $18(27.3)$ & $26(39.4)$ \\
\hline Electricity & \multicolumn{2}{|l|}{$12(18.2)$} & $33(50)$ & $21(31.8)$ \\
\hline Storage & \multicolumn{2}{|l|}{$7(10.6)$} & $59(89.4)$ & \\
\hline Natural capital & Yes & No & & \\
\hline Land & $65(98.5)$ & $1(1.5)$ & & \\
\hline Type of tenure & & & & \\
\hline Lease & 1 & $1(1.5)$ & & \\
\hline Permission to occupy & 2 & $65(98.5)$ & & \\
\hline
\end{tabular}




\section{Linear regression analysis of the impact of irrigation farming on livelihood strategies}

\section{Determinants of livelihood strategies among farmers on irrigation farming}

The results of the multiple regression analysis of the relationship between irrigation farming and livelihood strategies among farmers is presented in Table 3. From the results the independent variables were significantly related to livelihood strategies of the farmers with an $F$ value of $8.067, \mathrm{p}<0.05$ and $R$ value of 0.788 . This showed that there was a strong correlation between the independent variable and the livelihood strategies. Significant determinants were marital status (2.43), number of household $(\mathrm{t}=5.41)$, nonfarm activity $(\mathrm{t}=1.73)$ and income $(\mathrm{t}=6.59)$. This implies that the smaller the household and the higher the income from farming operations and nonfarm activities, farmers can meet their basic needs from irrigation farming and with more income they can also easily access many livelihood strategies available to them.

Table 3: Determinants of livelihood strategies among farmers in the irrigation scheme.

\begin{tabular}{|c|c|c|c|c|c|}
\hline Model & B & $\begin{array}{l}\text { Standard } \\
\text { Error }\end{array}$ & Beta & $\mathrm{t}$ & Sig \\
\hline Age & -1082.132 & 4273.636 & & -0.253 & 0.801 \\
\hline Marital status & 169.558 & 69.535 & 0.248 & 2.438 & $0.018 * *$ \\
\hline $\begin{array}{l}\text { Number of } \\
\text { dependents }\end{array}$ & 1866.871 & 1258.553 & 0.149 & 1.483 & 0.144 \\
\hline $\begin{array}{l}\text { Number of } \\
\text { household }\end{array}$ & -1937.116 & 357.507 & -0.640 & -5.418 & $0.000 * * *$ \\
\hline $\begin{array}{l}\text { Educational } \\
\text { level }\end{array}$ & -712.863 & 457.429 & -0.155 & -1.558 & 0.125 \\
\hline Labor source & 116.545 & 920.080 & 0.012 & 0.127 & 0.900 \\
\hline $\begin{array}{l}\text { Nonfarm } \\
\text { activity }\end{array}$ & -3034.821 & 1747.310 & -0.176 & -1.737 & 0.088* \\
\hline $\begin{array}{ll}\text { Type } & \text { of } \\
\text { irrigation } & \end{array}$ & 122.167 & 1360.175 & 0.009 & 0.090 & 0.929 \\
\hline Livelihood & 22.026 & 22.789 & 0.087 & 0.967 & 0.338 \\
\hline Food security & 1862.867 & 1430.381 & 0.123 & 1.302 & 0.198 \\
\hline Income & 0.171 & 0.026 & 0.631 & 6.590 & $0.000 * * *$ \\
\hline Expenditure & -0.017 & 0.120 & -0.013 & -0.146 & 0.885 \\
\hline $\mathrm{F}$ & 8.067 & & & & \\
\hline Sig & $0.000^{\mathrm{b}}$ & & & & \\
\hline $\mathrm{R}$ & $0.788^{\mathrm{a}}$ & & & & \\
\hline R Square & 0.622 & & & & \\
\hline
\end{tabular}




\section{Conclusion}

The study has shown that many farmers sustain their livelihoods through various enterprises based on irrigation farming. Their livelihood aspirations also depend on the sustainability of these enterprises. Farmers indicated that they have adequate access to livelihood assets such as physical capital, human capital, natural capital and skill training but access to financial capital, including credit from the banks, cooperative and government subsidies, was not adequate. The determinants of the livelihood strategies of farmers were marital status, size of household, nonfarm activity and income. The study emphasises the need to enhance access and control on livelihood capital in order to make their livelihoods sustainable.

\section{Acknowledgement}

This work was conducted through a project initiated, managed and funded by the Water Research Commission (WRC) entitled, "Empowerment of woman in rural areas through water use security and agricultural skills training for gender equity and poverty reduction in KwaZulu-Natal and North West Province (K5/2176)" as published in the WRC Knowledge Review (2012/13).

\section{References}

[1] Perret, S., Water policies and smallholding irrigation schemes in South Africa: A history and new institutional changes. Water Policy, 4(3), pp. 283-300, 2002.

[2] FAO. Small-scale irrigation for arid zones: Principles and options. Food and Agricultural Organisation, Rome, 1997a.

[3] FAO. Assessment of the socio-economic impact of smallholder irrigation development on smallholder farmers in Zimbabwe. A report prepared by R. Dhlodhlo for Food and Agricultural Organisation, 1997b.

[4] Lyne, M.C., Hendricks, S.L., Chitja, J.M. Agricultural growth and food security. In: S L Hendricks and M C Lyne (ed), Does food security improve when smallholders access a niche market? Lessons from the Embo Community in South Africa. The African Centre for Food Security, University of KwaZulu-Natal, South Africa. ISBN: 978-1-86840-687-6, 2009.

[5] Backeberg, G. Reform of user charges, market pricing and management of water: problem or opportunity for irrigated agriculture? Irrigation and Drainage, 55, pp. 1-12, 2006.

[6] Ellis, F. Rural Livelihoods and Poverty Reduction Policies: London, Routledge, 2000.

[7] De Satgé, R. Learning about livelihoods: Insights from Southern Africa. Cape Town: Periperi, 2002.

[8] Mutsvangwa, T. Agriculture and Sustainable Development, Netherlands, The Hague University Press, 2006. 
[9] Punnet, W. Man, Land and Resources: Yew York. Macmillan, 1982.

[10] Jackson, J. and Steenhuis, T. Environmental Issues. Small Hotters Sectors, University of Zimbabwe, 1997.

[11] Department of Agriculture Forestry and Fisheries (DAFF). The integrated Food Security Strategy for South Africa (2011), online: www.daff.gov.za

[12] Dalelo, A. The church and socio-economic development. Addis Ababa: EKHC Literature Department, 2003.

[13] Department of Agriculture Forestry and Fisheries (DAFF). Directorate: Food Security, Strategic outlook (2010-2015), 2010.

[14] Department of Agriculture Forestry and Fisheries (DAFF). National Issues: Food Security. Pretoria: The National Agricultural Directory 2007, pp. 53, 2012.

[15] Oladeeboo, J. O. and O.E. Oladeeboo. Determinants of loan repayment among smallholder farmers in Ogbomoso Agricultural Zone of Oyo State, Nigeria. J. Soc. Sci. 17 (1): pp. 59-62, 2008.

[16] Oruonye, D. and Musa, Y. N. Challenges of small scale farmers access to micro credit (Bada Kaka) in Gassol LGA, Taraba State, Nigeria.

[17] International Fund for Agricultural Development (IFAD). Rural poverty report 2001: the challenge of ending rural poverty. Oxford: Oxford University Press, 2001.

[18] Oduro, A.D., Osai-Akoto., Acquaye, I. Poverty in a Localizing World. The Role of Rural Institutions. Tokyo: FASID, 2004.

[19] Holloway, G.J., Charles, N., Christopher, D., Stevens, S., Simon, E. Agroindustrialization through institutional innovation: Transaction costs, cooperative and milk market development in East African Highlands. Agricultural Economics Journal, 23, pp. 279-288, 2000.

[20] Goletti, F. \& Wolff, C. The impact of post-harvest research. MSSD Discussion Paper 29. International Food Policy Research Institute, Washington DC, 1998.

[21] Montshwe, B.D. Factors affecting participation in mainstream cattle markets by small-scale cattle farmers in South Africa. Unpublished master's thesis. University of Free State, Bloemfontein, 2006. 